\title{
高エネルギー水素イオン注入透過法による金属中の 重水素の拡散係数の測定
}

\begin{abstract}
古山雄 一* 田辺哲 朗** 井本正介**
J.Japan Inst.Metals, Vol.50,No.8(1986),pp.688-694

Determination of Deuterium Diffusion Coefficient by Ion Driven

Permeation Technique

Yuichi Furuyama*, Tetsuo Tanabe** and Shōsuke Imoto**

In order to determine the deuterium diffusivity in metals, we have developed a new technique, ion driven permeation, in which implantation of energetic deuterium ions is utilized in stead of gaseous charging or electrochemical charging for deuterium permeation.

The deuterium permeation rate caused by the ion implantation is generally similar to those of the latter two techniques. The steady state permeation rate and the diffusion coefficient, however, tend to decrease with increasing duration of implantation (or with increasing implanted fluence) because of modification of surface and/or subsurface region by the ion bombardment. Therefore, the values of diffusion coefficient determined from initial permeation rise for a fully annealed specimen are reprpoducible and reliable.
\end{abstract}

The diffusion coefficiens thus determined are

$$
D_{\mathrm{Cu}}=8.2 \times 10^{-8} \exp \left(-23.3 \mathrm{~kJ} \cdot \mathrm{mol}^{-1} / R T\right) \mathrm{m}^{2} \cdot \mathrm{s}^{-1}
$$

and

$$
D_{\mathrm{Ni}}=3.9 \times 10^{-7} \exp \left(-38.6 \mathrm{~kJ} \cdot \mathrm{mol}^{-1} / R T\right) \mathrm{m}^{2} \cdot \mathrm{s}^{-1} \text {. }
$$

for deuterium in $\mathrm{Cu}$ and $\mathrm{Ni}$ at $500 \mathrm{~K}-1100 \mathrm{~K}$, respectively. Both are in good agreement with those values determined by the gaseous permeation technique.

Appling this technique to $\mathrm{Al}$, for which the value of hydrogen diffusion coefficient has been widely scattered due to the surface oxide, we can get the deuterium diffusion coefficient as

$$
D_{\mathrm{Al}}=1.4 \times 10^{-6} \exp \left(-35.7 \mathrm{~kJ} \cdot \mathrm{mol}^{-1} / R T\right) \mathrm{m}^{2} \cdot \mathrm{s}^{-1} \text {. }
$$

Since energetic deuterium goes directry into the bulk, the determined values seem not to be influenced by the surface oxide.

(Received April 14. 1986)

Keywords : hydrogen, deuterium, diffusion coefficients, permeation, ion driven permeation, copper, nickel, aluminum, energetic ion

\section{I. 序 論}

金属中の水素の拡散係数を測定するため熱放出，ガス透 過, 内部摩擦, 核磁気共鳴, あるいは中性子擬弾性散乱を
利用する方法など様々な実験技術が利用されている．この うち高温領域において利用できるのは，熱放出法およびガ ス透過法に限られている。乙かし両者とも，表面から放出 される水素ガスを分析定量する方法であるため，試料の表

* 大阪大学大学院生 (Graduate Student, Osaka University, Suita)

** 大阪大学工学部原子力工学科 (Department of Nuclear Engineering, Faculty of Engineering, Osaka University, Suita) 
面状態が測定結果に大きな影響をおよぼすことは避けられ ない。また熱放出法では金属中の水素の溶解度が小さいと 測定は難しい，一般に金属表面には酸化物が形成されてい る場合が多く，特に酸化物が水素ガス中でも安定なアル ミニウムやニオブ，バナジウムなどの場合には，熱放出法 あるいはガス透過法で求められた水素の拡散係数の値は 2〜3 桁にわたってばらついている(1)-(23).

最近，核融合炉第 1 壁に打ける水素の挙動を明らかにす るため, 金属試料に高エネルギー水素イオンを注入し，そ の後の水素の拡散透過挙動を調べるなど高エネルギー水素 を用いた研究が様々に行われるよらになってきた(24)-(32). そしてイオン注入された水素の透過から金属中の水素の拡 散係数を求めた報告が出されている(33)-(36).

このイオン注入透過法を用いると, 水素が高ェネルギー でいったん試料内部に打ち込まれるので，溶解度の低い金 属でも，あるいは酸化しやすい金属でも入射側表面の影響 を受けずに，水素の拡散係数を測定できることが期待され る.しかし現在のところイオン注入透過法による実験は測 定温度範囲が狭いものであったり(34)(35)，求められた拡 散係数がガス状透過実験で求められた拡散係数とやや異な る(36)など，その実験技術が必らずしも確立されたものに なっていない.

本研究では報告されている拡散係数にばらつきが少ない 銅, ニッケルを標準試料として，イオン注入透過法による 拡散㐿数の測定技術を高め, その結果をアルミニウムの拡 散係数の測定に応用した。

\section{II. 理 論}

高エネルギ一水素イオンを標的固体に注入すると，打ち 込まれた水素イオンは，標的固体の原子や電子との衝突を 繰り返しながら次第にそのエネルギーを失っていき，入射 エネルギーに応じた深さ (飛程) まで侵入する. 打ち込まれ た水素の標的内での分布 (Implanted profile)は, 水素の拡 散が無視できるような低い温度での測定によって明らかに されて怙り，入射エネルギーがほぼ $1 \mathrm{keV}$ 以上であれば 2 体衝突を基礎にした衝突の理論で求められるものとほぼ 一致している(37)-(41). そしてTRIM Code ${ }^{(42)}$ のようなモ ンテカルロ計算によって簡単に求めることができる．標的 内に打ち込まれて熱化した後, 水素はその濃度勾配に従っ て拡散していくものと考兄られているので標的固体内の水 素濃度の時間変化は, Fick の第 2 法則に従って

$$
\partial C(x) / \partial t=D \cdot \partial^{2} C(x) / \partial x^{2}+\phi_{0} \cdot G(E, x)
$$

で表わされる。ここでは, 横方向の拡散は無視できるとし て 1 次元で取り扱うことにする。 $D$ は拡散係数, $\phi_{0}$ は入射 フラックスで, $G$ はェネルギー $E$ で打ち込まれた水素の 分布である. 打ら込まれた水素の入射側表面への拡散係数 $\left(D_{1}\right)$ と裏面への拡散係数 $\left(D_{2}\right)$ は異っていることも考兄ら れるが，ここでは $D_{1}$ と $D_{2}$ は等しいものとみなす(Fig.1 および Fig. 12 参照).

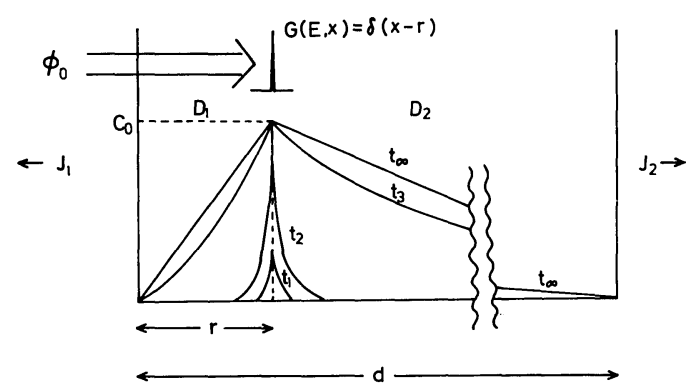

Fig.1 Concentration profiles of hydrogen implanted in metal.

$d$ : specimen thickness, $r$ : rang, $\phi$ : incident flux, $J_{1}$ : reemission rate, $J_{2}$ : permeation rate, $D_{1}, D_{2}$ : Diffusivity and $C_{0}$ : maximum concentration.

試料厚さが打ち込まれた時の分布のひろがり(range straggling) に比べて十分に大きい場合には, 試料中の水素 分布 $G(E, x)$ は Fig.1 に示すよらにデルタ関数で置き換 えることができる。

$$
G(E, x)=\delta(x-r)
$$

ここで $r$ は平均投影飛程である.

初期条件としてイオン注入される前の試料内の水素濃度 は, シーベルツの法則で示されるとすれば水素ガス圧を $P$, 溶解度定数を $S$ として

$$
C(x, t \leqq 0)=S P^{1 / 2}
$$

で与えられる。イオン注入中でも式（3)が成立して括り， かつ水素圧 $P$ が非常に小さいとすれば，境界条件として

$$
C(x=0, t)=C(x=d, t)=0 .
$$

定常状態で式 (1)を解くと，

$$
C(x, t=\infty)=C_{0} \cdot x / r \quad(o \leqq x \leqq r)
$$

および

$$
C(x, t=\infty)=C_{0} \cdot(d-x) /(d-r) \quad(r \leqq x \leqq d)
$$

が得られる. 試料表面から放出されてくる水素量(再放出 速度) $J_{1}$ と, 試料裏面から放出されてくる水素量 (透過速 度) $J_{2}$ とは, Fick の第 1 法則から

$$
\begin{aligned}
& J_{1}=\left.D \cdot \frac{\partial C}{\partial x}\right|_{x=0} \\
& J_{2}=-\left.D \cdot \frac{\partial C}{\partial x}\right|_{x=d}
\end{aligned}
$$

で与えられる，定常状態では入射フラックス $\phi_{0}$ は，

$$
\phi_{0}=J_{1}+J_{2}
$$

であるから

$$
C_{0}=\phi_{0} \cdot r \cdot(d-r) / D \cdot d
$$

となる. 従って, 定常状態での再放出速度と透過速度はそ れぞれ

$$
\begin{aligned}
& J_{1}=\phi_{0} \cdot(1-r / d) \\
& J_{2}=\phi_{0} \cdot r / d
\end{aligned}
$$

である、イオン注入を始めてから定常状態に達するまでの 式(1)の解は, 式 (3), (4)の境界条件のもとでフーリェ 変換を利用して求めることができ， 


$$
\begin{aligned}
C(x, t)= & \frac{2 \phi_{0} d}{D \pi^{2}} \sum_{n=1}^{\infty} \frac{1}{n^{2}} \cdot \sin \frac{n \pi r}{d} \\
& {\left[1-\exp \left(-\frac{n^{2} \pi^{2} D t}{d^{2}}\right)\right] \sin \frac{n \pi x}{d} }
\end{aligned}
$$

で与えられる．同様に定常状態からイオン注入を止めた時 に透過速度が零になるまでの解は

$$
\begin{gathered}
C^{\prime}(x, t)=-\frac{2 \phi_{0} d}{D \pi^{2}} \cdot \sum_{n=1}^{\infty} \frac{1}{n^{2}} \cdot \sin \frac{n \pi r}{d} . \\
\exp \left(-\frac{n^{2} \pi^{2} D t}{d^{2}}\right) \cdot \sin \frac{n \pi x}{d}
\end{gathered}
$$

で与えられる. その時の透過速度 $J_{2}$ は, 式 (7) 同様に Fick の第 1 法則に従って，それぞれ

$$
\begin{aligned}
& J_{2}=\frac{2 \phi_{0}}{\pi} \cdot \sum_{n=1}^{\infty} \frac{(-1)^{n}}{n} \cdot \sin \frac{n \pi r}{d}\left[1-\exp \left(-\frac{n^{2} \pi^{2} D t}{d^{2}}\right)\right] \\
& J_{2}^{\prime}=-\frac{2 \phi_{0}}{\pi} \sum_{n=1}^{\infty} \frac{(-1)^{n}}{n} \cdot \sin \frac{n \pi r}{d} \cdot \exp \left(-\frac{n^{2} \pi^{2} D t}{d^{2}}\right)
\end{aligned}
$$

で与えられる，ここでは式(14)，(15)をそれぞれ Injection Curve および Evolution Curve と呼び，Fig.2 に代表的 な曲線を示した。

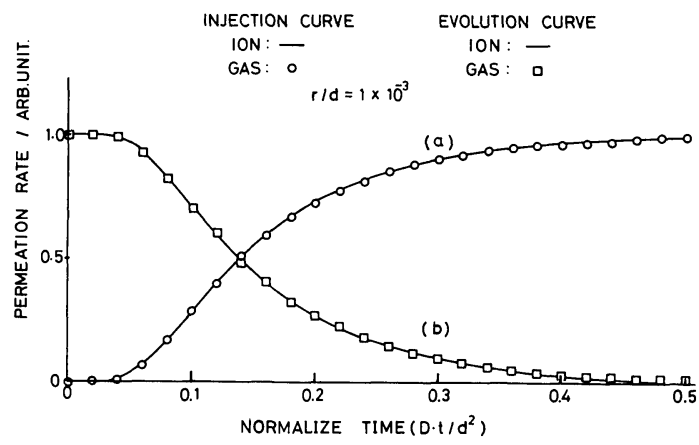

Fig.2 Time sequences of hydrogen permeation driven by energetic ion implantation (ion driven permeation) ; (a) injection given by eq. (14) and (b) evolution given by eq. (15)

ところで, 水素イオンの飛程 $r$ が試料厚さ $d$ に比べ非 常に浅い場合，すなわち $r / d \rightarrow 0$ の極限を考劣ると，式 (14)，(15) はそれぞれ

$$
\begin{aligned}
& J_{2}=\frac{D C_{0}}{d}\left[1+2 \sum_{n=1}^{\infty}(-1)^{n} \cdot \exp \left(-\frac{n^{2} \pi^{2} D t}{d^{2}}\right)\right] \\
& J_{2}^{\prime}=\frac{D C_{0}}{d}\left[-2 \sum_{n=1}^{\infty}(-1)^{n} \cdot \exp \left(-\frac{n^{2} \pi^{2} D t}{d^{2}}\right)\right]
\end{aligned}
$$

となり， $C_{0}=S P^{1 / 2}$ と置くとガス状の水素透過実験の場合 に等しくなる(43).

本実験では $30 \mathrm{keV}$ 重水素イオンを用いるので, イオン の飛程 $r$ は銅, ニッケルで約 $200 \mathrm{~nm}$, アルミニウムで約 $300 \mathrm{~nm}$ であるから ${ }^{(44)}$, 厚さ $100 \mu \mathrm{m}$ の試料を使った場合, $r / d$ は持よそ $10^{-3}$ となり, 裏面からの透過だけに着目す れば図 2 に示したよらに $r / d=1 \times 10^{-3}$ の時, 式(14), (15) から求めた Injection Curve, Evolution Curve とガス状水 素を考えた場合の式 (16)，(17)から求めたそれとの間には ほとんど差がない，ここではイオン注入による重水素の透
過を質量分析計によって検知定量し，その透過速度の時間 変化 (増加曲線, 減衰曲線)の実験結果に式 (16), (17) を最 小自乗法でフィッテングさせ拡散係数を求めた ${ }^{(33)}$.

\section{III. 実験}

Fig.3 (a)，(b) それぞれに実験装置の概略および試料取 り付け部の詳細を示した，実験装置は金属試料を隔壁とし てイオン注入系と測定系とに分けられて扣り，それぞれ独 立に排気されている。 RF イオン源で発生した重水素イオ ンは加速，収束され，分析磁石によって質量分析された 後, 直径 $0.8 \mathrm{~cm}$ の絞りを通って試料表面に注入される. 皎りと試料との間に置かれたファラデーカップは, 注入す るイオンフラックスの測定および試料へのイオンの注入の 開始と停止に使用される。本実験では残留軽水素 $\left(\mathrm{H}_{2}\right)$ の 影響を避けるため,すべて重水素 $\left(\mathrm{D}^{+}\right)$イオン(加速電圧 $30 \mathrm{keV}$ ，フラックス $\left.5 \times 10^{13} \sim 1 \times 10^{15} \mathrm{ions} / \mathrm{cm}^{2} \cdot \mathrm{s}\right)$ を用い た.イオン注入時の注入系内の圧力は， $1 \times 10^{-5} \mathrm{~Pa}$ 以下で あり，そのほとんどは $D_{2}$ であった。

直径 $1 \mathrm{~cm}$ の円板状試料を Fig. 3(b)に示したようにフラ ンジで圧封して装着した後，イオン注入系から測定系への ガスの漏れがないことを確めた．試料はモリブデンヒータ 一によって加熱し, その温度は温度調整器によって $\pm 10^{\circ} \mathrm{C}$ の精度で設定した，試料に注入された後，拡散透過して裏 面から放出される重水素は四重極質量分析計によって検出 定量された．測定系内の残留ガス圧は $2 \times 10^{-6} \mathrm{~Pa}$ 以下で ありそその主なるのは $\mathrm{H}_{2}$ であった。しかし，イオン注入 によって試料裏面から放出されてくるガスはほとんど $D_{2}$ であり，放出される HD はいずれの実験でも $D_{2}$ の $10 \%$

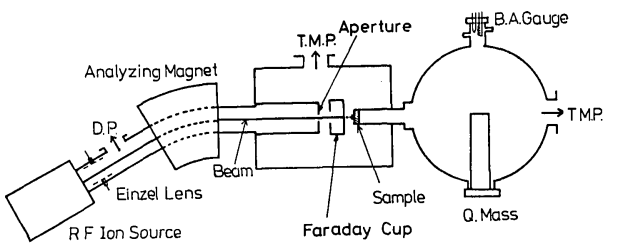

(a)

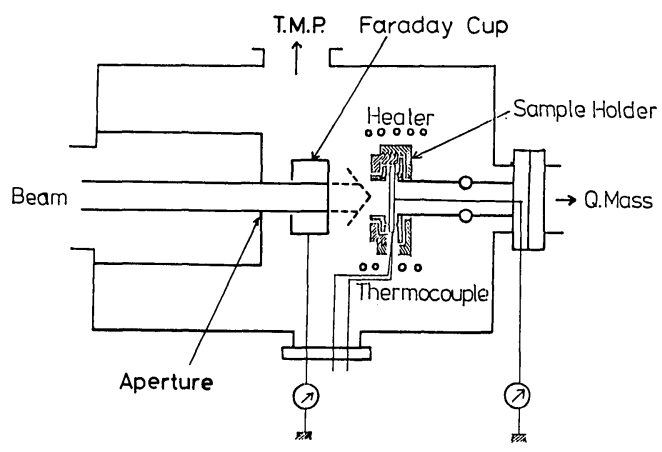

(b)

Fig.3 Apparatus for measurement of ion driven permeation. (a) Schematic diagram and (b) details of the sample holder. 
Table 1 Physical parameters of specimen.

\begin{tabular}{c|c|r|c|c}
\hline \hline \multirow{2}{*}{ Specimen } & \multirow{2}{*}{$\begin{array}{c}\text { Purity } \\
(\%)\end{array}$} & $\begin{array}{c}\text { Thickness } \\
(\mu \mathrm{m})\end{array}$ & \multicolumn{2}{|c}{ Annealing } \\
\cline { 4 - 5 } & & & $\begin{array}{c}\text { Temperature } \\
(\mathrm{K})\end{array}$ & $\begin{array}{c}\text { time } \\
(\mathrm{ks})\end{array}$ \\
\hline $\mathrm{Cu}$ & 99.999 & $40,100,300$ & 1173 & 3.6 \\
$\mathrm{Ni}$ & 99.999 & $10,20,50,100$ & 1173 & 3.6 \\
$\mathrm{Al}$ & 99.999 & 100 & 823 & 3.6 \\
\hline
\end{tabular}

以下であったので，ここでは HDの生成を無視した．測 定系の重水素に対する排気速度は $80 \mathrm{~L} / \mathrm{s}$, 系の真空時定数 は重水素に対して $8 \times 10^{-2}$ 秒であり, 系内への重水素の蓄 積の効果は無視できる.

Table 1 に実験で用いた試料の種類，その純度と厚さ および各実験前の焼鈍条件を示した，各試料は試料支持台 に取り付ける前に $0.3 \mu \mathrm{m}$ アルミナ粉末で鏡面研磨仕上げ を行った後，アセトン中で超音波洗浄をした．そして真空 中 $\left(2 \times 10^{-6} \mathrm{~Pa}\right)$ で十分な脱ガスを行った，再現性のよい結

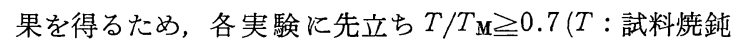
温度, $T_{\mathbf{M}}$ : 融点)で 1 時間以上焼鈍を行った。

\section{IV. 結 果}

Fig. 4 は $900^{\circ} \mathrm{C}$ で銅に $30 \mathrm{keV}$ 重水素イオンを注入した 時, 試料裏面から透過してくる単位時間当りの重水素量 (透過速度)の時間変化 (以後, 透過曲線之呼ぶ)を示したも のである。イオン注入された重水素の透過速度は時間と共

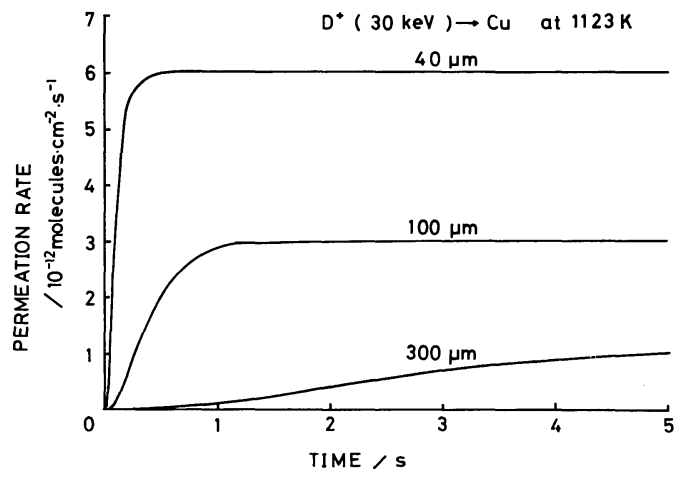

Fig. 4 Time sequences of deuterium permeation rate for $\mathrm{Cu}$.

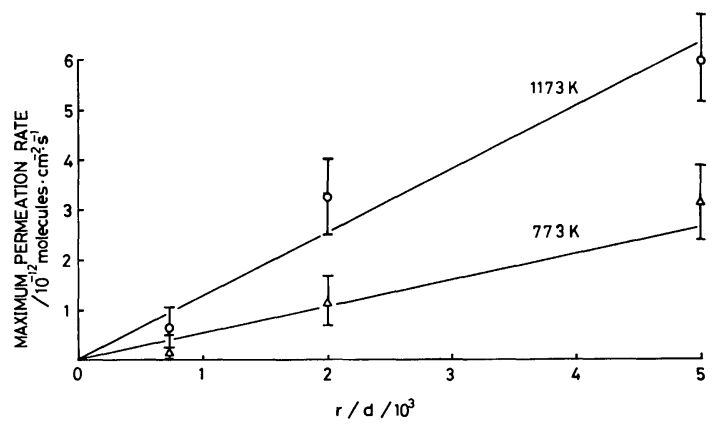

Fig. 5 Change in maximum permeation rate for $\mathrm{Cu}$ with specimen thickness.
に増加していき，やがて定常値を示すようになる．図から わかるように試料の厚さを $40,100,300 \mu \mathrm{m}$ と増すにつれ て，定常に達するまでの時間が長くなるが，一方透過速度の

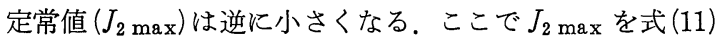
に従うものとして, $r / d(d$ : 試料厚さ, $r$ : 飛程 $)$ に対して プロットすると Fig.5 が得られる.図には $900^{\circ} \mathrm{C}$ と $500^{\circ} \mathrm{C}$ の結果を示したが，いずれの温度でも $J_{2} \max$ は $r / d$ にほぼ 比例して扣り，イオン注入された重水素の透過挙動は拡散 によって律速されているとみなすことができる。そこで照 射開始から定常値に達するまでの透過曲線(増加曲線とい う) の実験值に式(16) を拡散係数 $D$ をパラメータとして最 小自乗法フィッテングさせ，拡散係数を計数した。 Fig.6 に厚さ $300 \mu \mathrm{m}$ 銅試料の $900^{\circ} \mathrm{C}$ に打ける増加曲線のフィッ テングの一例を示したが, 実験值と式 (16)の曲線とは非常 に良く一致している。

同様にして様々な温度に打ける増加曲線から拡散係数 を求め, その值を温度逆数に対してプロットしたものが

Fig.7 中の白丸(Injection)である. 非常に良い直線性を示 し, その温度依存性は

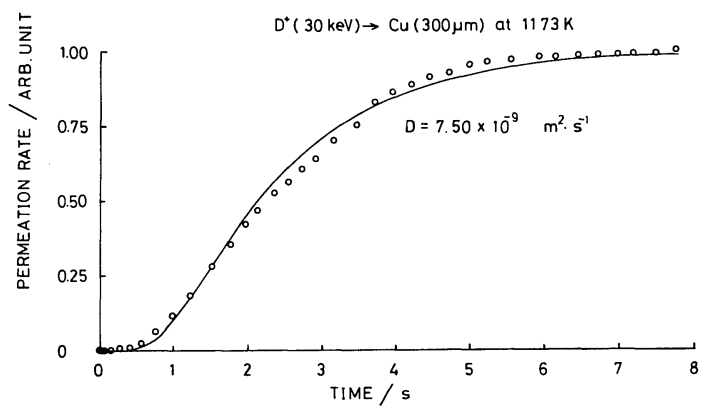

Fig. 6 Determination of diffusion coefficient by least square fitting method with eq. (16).

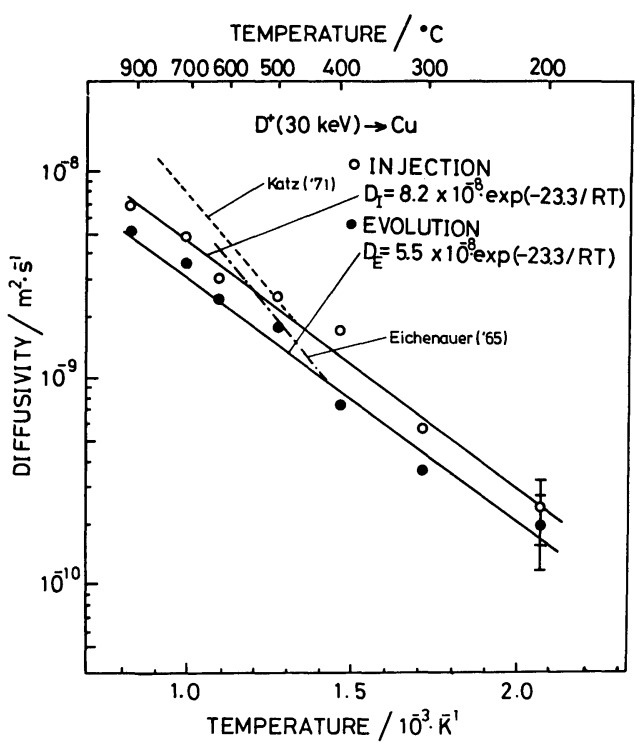

Fig.7 Temperature dependence of diffusion coefficient of deuterium in $\mathrm{Cu}$ determined by ion driven permeation. 
$D_{\mathrm{Cu}}=8.2 \times 10^{-8} \exp (-23.3 \mathrm{~kJ} \cdot \mathrm{mol} / R T) \quad \mathrm{m}^{2} \cdot \mathrm{s}^{-1}$

と表わせる．活性化ェネルギーはやや異っているが，ガス 状重水素透過実験から求められている拡散係数(破線拉よ び一点鎖線で示した)の值と全温度領域で良い一致を示し ている(45)(46).

ところで，重水素の注入を長く続けると透過速度はほぼ 定常值 $\left(J_{2 \max }\right)$ に達した後, 徐々に減少する. Fig.8 は $500^{\circ} \mathrm{C}$ で $30 \mathrm{keV}$ 重水素イオンを長時間にわたって注入し たとき, 透過速度が時間と共にどのよらに変化していくか を示したものである. ここではイオン注入開始後, 150 秒 で一度イオン注入を止めた後, 再びイオン注入を行った場 合の透過速度の変化を示している。また図には式(16) また は式(17)を用いて最小自乗法によりフィッテングさせて求 めた拡散係数を示す. 照射直後の拡散係数は $3.0 \times 10^{-9}$ $\mathrm{m}^{2} \cdot \mathrm{s}^{-1}, 150$ 秒後のそれは $8.6 \times 10^{-10} \mathrm{~m}^{2} \cdot \mathrm{s}^{-1}$ (減衰曲線から

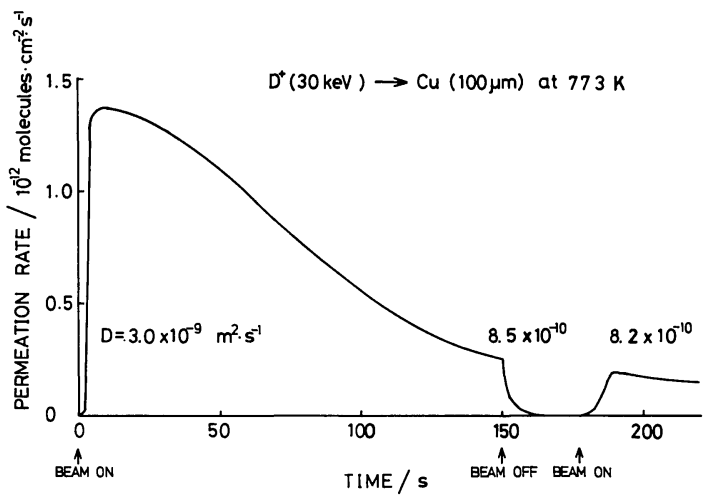

Fig. 8 Change in deuterium permeation rate for long time irradiation. Ion implantation was once interrupted for determination of diffusion coefficient.

TEMPERATURE $/ \cdot{ }^{\circ} \mathrm{C}$

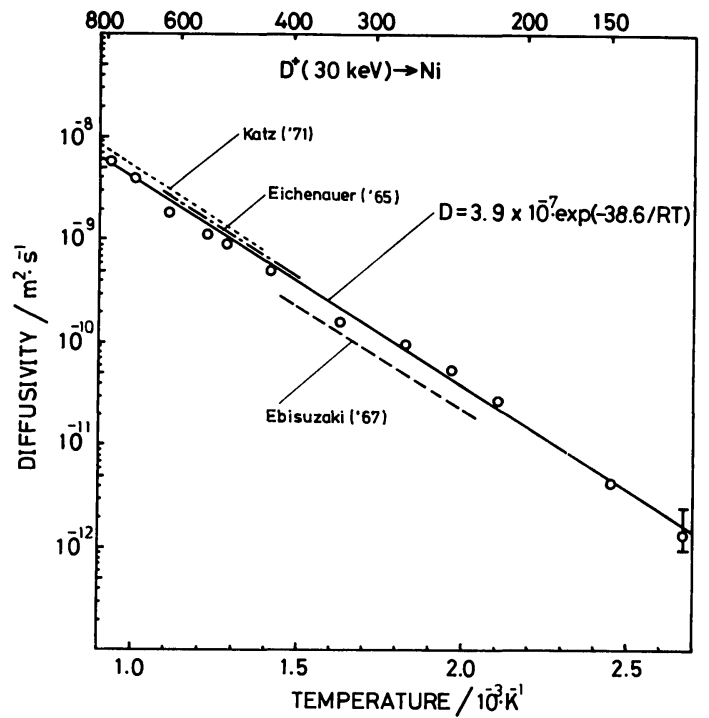

Fig.9 Temperature dependence of deuterium diffusion coefficient in $\mathrm{Ni}$ determined by ion driven permeation.
求める), その直後の増加曲線では $8.2 \times 10^{-10} \mathrm{~m}^{2} \cdot \mathrm{s}^{-1}$ であ り, 照射時間の増加につれて小さくなっている.

Fig.7 の黒丸(Evolution)は，イオン注入による透過速 度がほぽ定常值になった直後, 注入を止め, その減衰曲線 から求めた拡散係数を示したものであるが, 図からわかる ように最初の值(白丸)に比べて小さくなっている。この現 象はニッケルやモリブデンについても見られるもので，す でに詳しく報告した ${ }^{(31)-(33)}$.

ニッケルについても銅同様, 注入開始より定常に達す るまでの透過曲線から得られる拡散係数の值を温度の逆数 に対してプロットすると，Fig.9 が得られる。その温度依 存性は図の直線から

$$
D_{\mathrm{Ni}}=3.89 \times 10^{-7} \exp \left(-38.6 \mathrm{~kJ} \cdot \mathrm{mol}^{-1} / R T\right) \quad \mathrm{m}^{2} \cdot \mathrm{s}^{-1}
$$

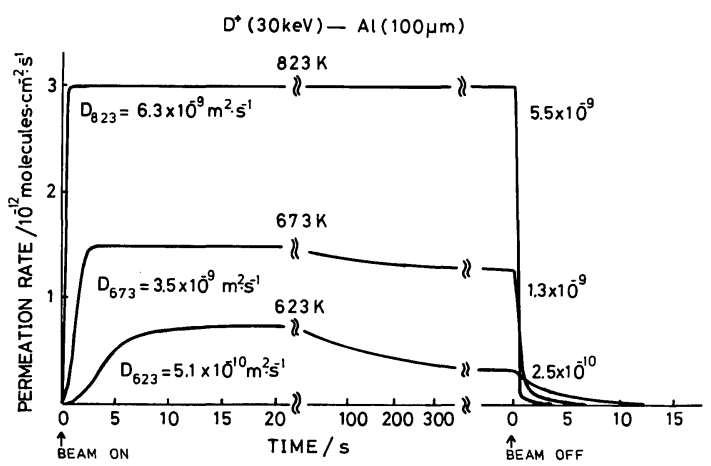

Fig.10 Time sequences of ion driven permeation for $\mathrm{Al}$.

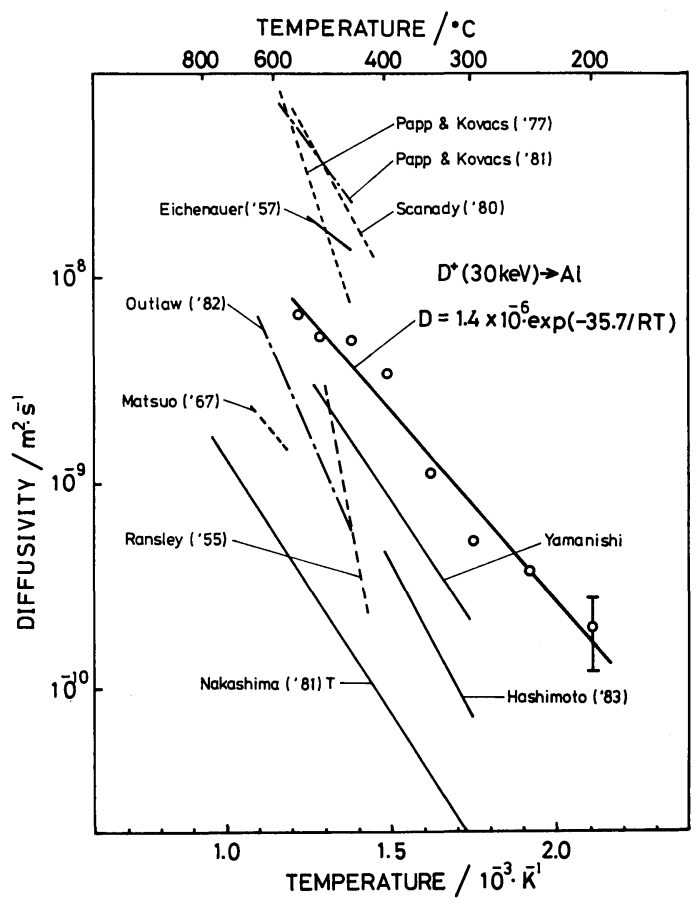

Fig.11 Temperature dependence of deuterium diffusion coefficient in Al determined by ion driven permeation. 
である，得られた結果は，ガス状重水素を用いた值と幅広 い温度領域にわたって非常に良く一致している(45)-(47).

このように銅およびニッケルの測定結果から，イオン注 入透過法が拡散係数の測定法として有用で, 正確な拡散係 数を与えることが確認された。 そこでこの方法を拡散係数 の文献值に大きなばらつきのあるアルミニウムに応用した。 Fig.10 はアルミニウムにイオン注入した時の透過速度の 時間変化の一例である.アルミニウムの透過挙動は, 銅, ニッケルと同様で, $550^{\circ} \mathrm{C}$ では透過速度はあまり減少しな いが $500^{\circ} \mathrm{C}$ 以下では透過速度は照射時間と共に減少する。 銅やニッケル同様，焼鈍された試料に対する増加曲線は式 (16)に良く合い最小自乗法によるフィッテングにより拡散 係数を求めることができた，減衰曲線から求めた拡散係数 は増加曲線から求めたものに比べるとやはり小さくなって いる. 増加曲線から求めた拡散係数を温度の逆数に対して プロットすると Fig.11 が得られる. 銅やニッケルの場合 に比べ，データのばらつきはやや大きいが幅広い温度領域 で良い直線性を示して拈り，その温度依存性は

$$
D_{\mathrm{Al}}=1.4 \times 10^{-6} \exp \left(-35.7 \mathrm{~kJ} \cdot \mathrm{mol}^{-1} / R T\right) \quad \mathrm{m}^{2} \cdot \mathrm{s}^{-1}
$$
で与えられる。

\section{V. 考察}

本実験ではイオン注入後, 金属裏面へ透過する重水素の 透過速度の増加曲線から，まず銅，ニッケル中の重水素の 払散係数を求め, これらについては文献値と良い一致を見 たので，同じ方法をアルミニウムに適用した．アルミニウ ムの拡散係数の報告值には著しいばらつきがあるが，これ は銅やニッケルと異なり，その表面に存在する酸化物のせ いであると考觉らててるる(48)-(51)。 。た表面に存在する 酸化物は重水素のイオン注入によっても還元されないこと が確められて扣り ${ }^{(52)}$, 本実験で求められた拡散係数がこ の表面酸化物の影響を受けている可能性がある.

表面酸化物の水素透過に及ぼす影響は定量的には評価さ れていないが，ここでは，仮に酸化物中の水素の拡散が遅 いものとして，次のようにその影響を式 (1) に従って評価 してみた。すなわち注入側の拡散係数が酸化物の存在のた めバルクのものより 1 桁小さいと仮定し $\left(D_{1} / D_{2}=0.1\right)$, 式 （1）を数值計算によって解き ${ }^{(53)}, D_{1}=D_{2}$ の場合と比較し た (Fig . 12)． $D_{1} / D_{2}=0.1$ の場合の増加曲線(定常值を 1.0 として規格化されている)は， $D_{1} / D_{2}$ の場合と比べてあまり 変化していない、いいかえると, 表面酸化物中の拡散が非常 に短かい時間内で著しく変化しない限り，アルミニウムの ように表面酸化物が存在してもガス状水素を使った透過実 験とは異なり，増加曲線はその影響をあまり受けないこと になる、本実験で得られたアルミニウム中の重水素の拡散 係数は, Scanady ${ }^{(9)}$, Papp と Kovacs ${ }^{(7)(8)}$, Eichenauer ${ }^{(1)}$ らの値よりも小さいが, Outlaw ${ }^{(2)}$, Hashimoto ら ${ }^{(5)}$ の値よ り大きく，純アルミニウムの結果として信頼性のあるもの と見なせる。

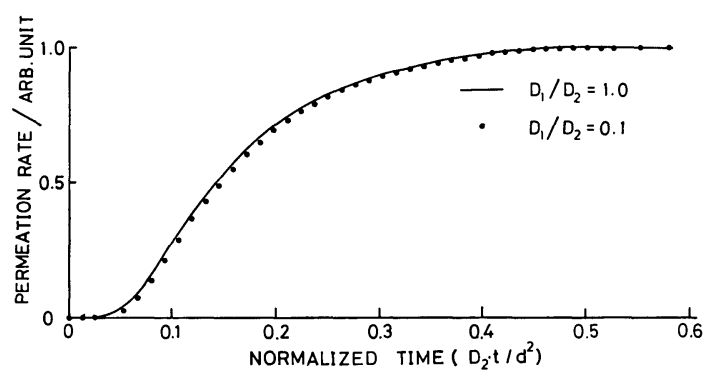

Fig.12 Comparison between time sequences of hydrogen permeation rate in ion driven permeation for $D_{1} / D_{2}=0.1$ and $D_{1} / D_{2}=1.0$.

(See also Fig.2 and Fig.3).

ところで，イオン注入を続けていくと Fig.8 と Fig.10 に示したように, その透過速度が減少すると共に拡散係数 も減少する，この透過速度の減少は本研究で示した銅，二 ッケル，アルミニウムだけでなく，鉄 ${ }^{(54) や ス テ ン レ ス ~}{ }^{(55)}$ なども見出されており，入射側表面での水素濃度の減少に よるとされているが，その原因として次の 3 つが考光られ ている，すなわち，(1) 水素イオン照射により注入側表面 の酸化物が還元されたりあるいはスパッタリングによる表 面の変化により，注入された水素の入射側表面での再放出 過程が早められる(56)(57)，(2) 水素イオン照射により飛 程より表面側にできた高密度の欠䏚が水素の拡散を促進 し, 再放出を早める(31).（3）飛程より内部にできた比較 的密度の薄い欠陥が水素のトラップ座となって水素を動き にくくし，透過速度を減じるとともに見かけの拡散係数を 小さくする(33)

いずれが主因であるかについては，様々に議論されて拉 り定説は無い。しかし重水素の照射によって表面酸化物が 還元されないアルミニウムでも，酸化物のない銅，ニッケ ル同様, 透過速度の減少が引き起こされることは, 田辺 $ら^{(31)-(33)}$ ，紀ら ${ }^{(58)}$ ，相良ら ${ }^{(59)}$ によって報告されているよ らに，水素注入によって引き起こされる転位ループやバブ ル生成など照射に伴う表面近傍の欠陥生成が重水素の拡散 に重要な役割を持っていることを示唆している.

\section{VI. 結 論}

イオン注入透過法により拡散係数を求める方法を開発 し，銅およびニッケルを用いて重水素の拡散係数を測定し た結果

$$
\begin{array}{ll}
D_{\mathrm{Cu}}=8.2 \times 10^{-8} \exp \left(-23.3 \mathrm{~kJ} \cdot \mathrm{mol}^{-1} / R T\right) & \mathrm{m}^{2} \cdot \mathrm{s}^{-1} \\
D_{\mathrm{Ni}}=3.9 \times 10^{-7} \exp \left(-38.6 \mathrm{~kJ} \cdot \mathrm{mol}^{-1} / R T\right) & \mathrm{m}^{2} \cdot \mathrm{s}^{-1}
\end{array}
$$

を得た，両者ともに文献值と良い一致を示していることか らイオン注入透過法が拡散係数測定に非常に有用であるこ とが確認された。ただし，長時間照射を続けると求められ る拡散係数は照射の影響を受けて小さくなるので, 試料は 十分に焼鈍されたものでなければならない，本方法をアル ミニウムに適用し, 重水素の拡散係数 
$D_{\mathrm{Al}}=1.4 \times 10^{-6} \exp \left(-35.7 \mathrm{~kJ} \cdot \mathrm{mol}^{-1} / R T\right) \quad \mathrm{m}^{2} \cdot \mathrm{s}^{-1}$

を得た。この值は表面酸化物に影響されていないアルミニ ウムの拡散係数として信頼性の高いものと考えられる。

\section{文献}

(1) W. Eichenauer and A. Pebler : Z. Metallk., 48 (1957), 373.

(2) R.A.Outlaw, D.T.Peterson and F.A.Schmidt: Scripta Metall., 16(1982), 287.

(3) M.Nakashima, N.Aratono and E.Tachikawa: J.Nuc1. Mater., 98(1981), 27.

（4）松尾 茂, 平田俊也：日本金属学会誌, 31 (1967), 590 .

(5) E.Hashimoto and T.Kino : J.Phys.F.Met.Phys., $13(1983), 1157$.

(6) C.E.Ranskey : Z.Metallk., 45 (1955) , 328.

(7) K.Papp and E. Kovacs:Scripta. Metall., 11 (1977), 921.

(8) K. Papp and E. Kovacs : Scripta. Metall., 15 (1981), 161.

(9) A.Scanady and K.Papp:Mater. Sci. Engineering, 48 (1981) , 35

(10) I.N.Andrew, H.H. Lee and A.G.Quarrell:J.Iron Steel Inst., 146(1942), 181

(11) 山西雄司 : 修士論文, 大阪大学 (1983).

(12) G.E.Moore : J.Chem.Phys., 40 (1964), 2639.

(13) W.M.Albrecht, W.D.Goode and M.W.Mallet : J. Electrochem. Soc., 105 (1958), 219.

(14) W.M.Albrecht, W.D.Goode and M.W.Mallet : J. Electrochem. Soc., 106 (1959), 981.

(15) G. Schaumann, J. Volk1 and G.Alefeld : Phys. Status Solidi, 42 (1970), 401.

(16) T.O.Ogurtani : Met.Trans., 2 (1971), 3035.

(17) C.Baker and H.K.Birnbaum : paper presented at the international meeting on Hydrogen in Metals March 20-24, 1972, Julich, Germany.

(18) J. Volkl : paper presented at the international meeting on Hydrogen in Metals, March 20-24, (1972), Julich, Germany.

(19) R.M.Cotts : paper presented at the international meeting on Hydrogen in Metals, March 20-24 (1972), Julich, Germany.

(20) W.Gissler : paper presented at the international meeting on Hydrogen in Metals, March 20-24 (1972), Julich, Germany

(21) G.Cantelli, F.M.Mazzolai and M.Naoro : paper presented at the international meeting on Hydrogen in Metals, March 20-24 (1972), Julich, Germany.

(22) J.M.Rowe, K. Skold, H.E.Flotow and J.J.Rush: J.Phys. Chem. Solids, 32 (1971), 41.

(23) R.Cantelli, F.M. Mazzolai and M. Nuovo: J. Phys. Chem. Solids, 31 (1970), 1811.

(24) P.Borgesen, B.M.U.Sherzer and W.Moller : J. Appl. Phys., 57 (1985) , 2733.

(25) P.Borgesen, B.M.U.Sherzer and W. Moller : Nucl. Instr. Meth., B7 (1985) , 67.

(26) P.Borgesen, B.M.U. Sherzer and W.Moller : Nuc1. Instr. Meth., B9 (1985) , 33.

(27) D. Presinger, D. P. Borgensen, W. Moller and B.M.U.Scherzer : Nucl. Instr. Meth., B9 (1985), 270.

(28) E. Rota, F. Woelbroeck, P. Wienhold and J. Winter: J.Nucl. Mater., 111 \& 112(1982), 233.
(29) A.E.Gorodetsky, A.P.Zakharov, V.M.Sharapov and V.Kh. Alimow : J.Nucl. Mater., 93 \& 94 (1980), 588.

(30) H.K.Perkins and T.Noda : J.Nucl. Mater., 71 (1978), 349 .

(31) T.Tanabe, Y.Furuyama and S.Imoto : J.Nucl. Mater., 122 \& $123(1984), 1563$.

(32) T.Tanabe, Y.Furuyama, H.Hirano and S.Imoto: J.Nucl Mater., 128 \& $129(1984), 641$.

(33) T.Tanabe, N.Saito, Y.Etoh and S.Imoto: J.Nucl. Mater., 103 \& 104 (1981), 483.

(34) W.J.Kass : Proc. Intern. Cong., Effect of Hydrogen on Behavior of Materials, AIME, (1975) , 327.

(35) W.Moller, F.Besenbacher and J.Bottiger : Appl. Phys., A27 (1982), 19.

(36) A.Tahara and Y.Hayashi:Trans. JIM, 26 (1985), 869 .

（37）志水隆一：応用物理, 50 (1981)，470.

(38) N. Matsunami, Y. Yamamura, Y. Itikawa, N. Itoh, Y.Kazumata, S.Miyagawa K. Morita and R. Shimizu : Repot. IPP, Nagoya University, IPPJ-AM-14 (1980) .

(39) T.Tabata, R.Itoh, Y.Itakawa, N.Itoh and K. Morita : Repot. IPP, Nagoya University, IP PJAM-18 (1981)

(40) W.Eckstein and H.Verbeek : J.Nucl. Mater., 93 \& $94(1980), 518$

(41) E.W.Thomas, R.Young and J.E.Harris: J.Nucl. Mater., 93 \& 94 (1980), 524.

(42) J.P.Biersack and L.G.Haggmark : Nucl. Instr. Meth., 174 (1980), 257.

(43) T.Tanabe, Y.Yamanishi and S.Imoto: Trans. JIM, 25 (1984) , 1.

(44) H.H.Andersen and J.F.Ziegler: Stopping Powers and Ranges in All Elements, Vol.3, Pergamon Press, (1977).

(45) W. Eichenauer : Z.Metallk., 56(1965), 287.

(46) L.Kats : Phys. Rev., 134 (1971), 330.

(47) Y.Ebisuzaki, W.J.Kass and M.Okeefee:J.Chem. Phys., 46(1967) , 1373.

(48) C.E. Ransley and D.E. Talbot : Z. Metallk., 46 (1955) , 328.

(49) W. Eichenauer and A. Pebler: Z. Metallk., 48 (1957) , 373.

(50) W.Eichenauer, K. Hattenbach and A.Pebler : Z. Metallk, 52(1961), 682 .

(51) C. N. Cochran : J. Electrochem. Soc., 108(1961), 317 .

(52) T.Tanabe and S.Imoto : J. Nucl. Mater., 128 \& $129(1984), 749$.

(53) T.Tanabe, K. Sawada and S.Imoto : Trans. JIM, $27(1986), 321$

(54) J.Winter, F.Waelbroeck, P.Wienhold and T. Schelske : J. Nucl. Mater., 111 \& 112(1982), 243.

(55) R.A.Causey, R.A.Kerst and B.E.Mills: J. Nucl. Mater, 122 \& 123 (1984), 1547.

(56) R.Bastasz, R.A.Kerst and R.A.Causey:J.Nucl. Mater., 122 \& 123 (1984), 1412.

(57) W.R.Wampler:J.Nucl. Mater., 122 \& 123 (1984), 1598.

(58) 紀 隆雄 : 核融合材料としてのアルミニウム基合金 の基礎的研究，文部省科件費補助金エネルギー特別 研究第一班報告書 1983 年 3 月 70 頁.

(59) A.Sagara, K. Kamada, S. Yamaguchi, H. Kinoshita and H.Takahashi : Proc. 2nd Intern. Conf. Fusion Reactor Materials (1986), April 13-19(1986), Chicago. 